\title{
AN ANALYSIS OF MORPHOLOGICAL AND SYNTACTICAL ERRORS IN RECOUNT TEXT
}

\author{
Noening Poejilestari \\ Sekolah Tinggi Bahasa Asing - IEC Bekasi \\ noening@stibaiecbekasi.ac.id
}

\begin{abstract}
Poejilestari, N. (2020). An analysis of morphological and syntactical errors in recount text. Journal of English
\end{abstract} Language and literature, 5(1), 9-18. DOI 10.37110/jell.v5i01.91

Received: 09-01-2020

Accepted: 01-02-2020

Published:01-03-2020

\begin{abstract}
The purpose of this study is to determine the morphological errors and syntactic errors made by students in writing recount text, frequency of errors, types of dominant errors and sources of errors. The research method used is qualitative research. The data from this study are 70 recount texts made by students of tenth grade in SMK Negeri 9 Kota Bekasi. The research found that there were still many mistakes made by the tenth grade students of SMKN 9 in Bekasi in writing English recount text. For morphological errors the researcher found that students made 56 errors which included single errors with the number of errors $4(7.14 \%)$, plural form errors with number of errors $5(8.93 \%)$, errors belonging to the number of errors $8(14.29 \%)$, errors to infinitive with the number of errors $9(16.07 \%)$ and the formation error in the past with the number of errors $30(53.57 \%)$. While for syntactic errors, the researcher found that students made 113 errors which included omission errors with 47 errors (41.60\%), addition errors with 24 errors (21.24\%) and formation errors with 42 errors $(37.16 \%)$. This shows that grammar is a weakness of students in writing essays, especially recount text. From the results of the study it was found that students experienced obstacles in writing caused by interlingual factors, intralingual factors and excessive generalization. Thus students' writing skills are still weak.
\end{abstract}

Keywords: morphology; syntax; error; recount text; qualitative

\section{INTRODUCTION}

Most Indonesians have their local language as their first language and Bahasa as the second language. This condition makes English become a foreign language in Indonesia. When Indonesians begin to learn foreign language, particularly english, the situation is not easy for them. It means, learning English for Indonesians means learning foreign language which mastery and knowledge of grammar in Bahasa will create obstacles in foreign language that resulting interesting errors to be used as study object.

Indonesian students study english from elementary to senior high school, but they still have much difficulties in english, and english becomes more difficult when the students are asked to speak or write good english as well. This happen because writing is a complex activity that includes mechanics of writing including hand writing, spelling and the basics of language knowledge.
In order to write a good english text, several aspects of language must be taken into consideration namely morphology, syntax, semantics and pragmatism (Bauer, 2007). Writing is a skill that is hard to master as many different types of errors can occur during this process. Flynn \& Stainthorp (2006) state that writing is a complex task that requires cognitive skills or learners and the ability to perform different activities simultaneously. Many EFL (english as a foreign language) learners encounter writing difficulties and one of the major is linked to english grammar (Belkhir \& Benyelles, 2017). Cam \& Tran (20170 found that the lack of grammatical knowledge is responsible for students' deficiency in english. It can be said that in mastering the writing, the learners should master the other components, such as morphology, syntax, semantic, grammar, etc.

Unfortunately, the teacher usually forgets to pay attention to all of those aspect above. In 
fact, the teacher only gives the topics that have to be written and asks them to make a good writing based on it. As the result, the students often make many errors in writing a good english text because of several reasons. First, the students have to translate their ideas into english; second, the students have to apply the english rules in making the sentences; third, a lot of students are not familiar with english grammar; fourth, the students interfered by their mother tongue rules which they apply in english written.

This study focuses on writing competence, especially errors in writing recount text. In recount text students must use the grammar of the past form when writing sentences. The use of past tense grammar by high school students is considered more complicated than the present tense grammar. In their use, the students must change the verb (regular and irregular verb) into past form.

Therefore, in this study, the researcher wants to know the forms of morphological and syntactic errors that are often made by tenth grade students in writing recount text. The main discussion in this study about grammatical errors contained in recount text written by tenth grade students of SMK Negeri 9 Kota Bekasi. The selection of tenth grade is considered appropriate for the reason that tenth grade students is considered to have mastered English well and correctly, and recount topic in accordance with the syllabus.

This research is conducted to answer the following questions:

a. What kinds of morphological errors found in English recount text written by students of SMKN 9 Bekasi

b. What kinds of syntactic errors found in English recount text written by students of SMKN 9 Bekasi Bekasi

c. What are the source of errors found in English recount text written by students of SMKN 9 Bekasi

\section{REVIEW OF LITERATURE \\ Error Analysis (EA)}

Error analysis (EA) appeared in the 1970s to discuss the errors made by language learners. EA offered an alternative view towards learners' errors compared to contractive analysis (CA). According to error analysis, learners' errors are not only caused by the native language but also by more universal learning strategies (Richards \& Schmidt, 2002). The fact that learners' errors can be observed, analyzed, and clarified to reveal the learners' errors became the basis for EA to investigate the errors. It is in contrast to CA which views that the learners' errors in the target language is the result of interference from their first language (Brown, 2007; Khansir, 2012).

EA replaced CA in the early 1970s because of the following reasons (SavilleTroike, 2006):

a) The errors that were predicted by CA do not always occur in actual learners' errors. Many of learners' errors did not relate to the L1 interference.

b) As the theory of linguistic has changed, the concern for structural linguistic moved from surface-level forms and patterns to fundamental rules.

c) Linguists and psychologists questioned have the assumption of behaviorists who believe that habit formation is a part of language acquisition.

Corder (in Ellis, 1994) as the mover of the analysis of learners' errors refocused the errors from the perspective of the language process and language acquisition. Corder suggested five steps to analyze the learners' errors: sample collection, errors identification, errors description, errors explanation, and errors evaluation.

The first step is collecting sample data for analysis. The researcher may control the data by narrowly specifying the sample that they intend to collect. Some researchers used samples that were collected in periods of weeks, months, or even years in order to determine patterns of error utterances.

The second step is the identification of errors. In this step, the researcher identified the errors by comparing the learners' sentences with the corresponding native sentences. Then, the researcher identify which parts of the learners' sentences were different from the natives' sentences.

The third step is a description of the errors. In this step, the researcher describes the errors using the surface strategy taxonomy in order to describe the difference between learners' sentences and the corresponding native's sentences. Corder (in Ellis, 1994) classified the errors into three types:

a) Presystematic errors occur when the learners were not conscious of the existence of particular rules in the target language.

b) Systematic errors occur when the learners had the understanding of the rule but the rule was an incorrect one. 
c) Postsystematic errors occur when the learners produced errors inconsistently even when they understood the rules.

The fourth step is an explanation of the errors. In this step, the researcher determines the sources of error, in order to find the reasons for the learners' errors. The last step is the evaluation of errors. In this step, the researcher determines which parts of the errors need more explanation or attention. Those five steps are important in order to analyze and understand the learners' errors.

\section{Notions of Error}

In the process of language learning, there were some possibilities that the learners might produce errors in the target language. The second and foreign language learner did not always produce errors; even the first language learner often sometimes produce errors. Ellis (1994) stated that not only the second language learners made errors, but also children who learnt their first language as well as native adults.

There are two essential terms that should be distinguished when analyzing errors in the learning of a foreign language. These are errors and mistakes. These two terms are used to relate

to the failure of using correct utterances in the target language. Errors occurred when the learners produce errors that were new rules for them, while mistakes are incorrectly applied rules (Krisnawati, 2013). Moreover, Ellis (1994) claimed that errors occur because of lack of knowledge. On the other hand, mistakes occur when learners fail to apply their language skills.

Errors and mistakes can be also distinguished by their corrigibility. James (1998) define errors as instances of language that were not self-corrigible by their writers whereas mistakes can be both intentional or unintentional language deviants and are usually self-corrigible by their writers. This means that the learners cannot correct their own errors, but they can correct their own mistakes. In addition, Tarigan (2011) argued that errors were caused by the learners' incompetence, while mistakes were caused by the learners' performance. It can be concluded that errors occurred because of lack knowledge of the learners towards the target language and occur consistently and systematically.

\section{Classification of Errors}

Dulay et al. (1982) categorized language errors into four taxonomies. These were (1) the linguistics category, (2) the surface structure taxonomy, (3) the comparative taxonomy, and (4) the communicative effect taxonomy. This research only uses the surface structure taxonomy. The surface structure taxonomy is used to explain the error phenomena. Dulay et al. (1982) wrote that learners might omit necessary items, add unnecessary items, misform the items, or disorder the items. Ellis (1994) also added that the omission indicates the omission of a certain linguistic item that must not appear in a wellformed utterance, addition indicates the addition of a certain linguistic item that must not be appeared in well-formed utterance, misformation indicates the use of an incorrect form of a certain linguistic in the target language utterance, and disordering indicates the incorrect arrangement of a certain linguistic in the target language utterance

\section{Sources of Error}

The two main sources of errors in the learning of a new language are interlingual and intralingual errors (Brown, 2007). Interlingual errors come from interference from the first language. In this context, the first language is Bahasa which is the interferer and English as the target language is the interfered. On the other hand, intralingual errors occur when language learners produce the language using their own creativity. Richard (1974) added that another source of error was developmental errors which occur when learners attempt to build up their own hypotheses of the target language based on their own limited knowledge and experiences. Intralingual errors are the most common type of error. Richard (1974) offered four types of intralingual errors:

a) Overgeneralization

Overgeneralization occurs when the students cannot use the rule of the target language correctly. Overgeneralization covers errors that are produced by learners when they try to apply a correct rule in an unsuitable situation. An example from Ellis (1994) is as follows: He cans sing.* He can sing.

b) Ignorance of Rule Restriction

This source of error occurs when the students cannot use the exception rules. Richard (1974) explained that the ignorance of rule restriction is closely related to overgeneralization. This type of error occurs when a rule is not used in the context where 
it should have been used. An example from Ellis (1994) is as follows: He asked me to*

He asked me to go.

c) Incomplete Application of the Rule

This source of error occurs when the students are unable to present some important elements in a word, phrase, or sentence. Richard (1974) pointed out that the incomplete application of rules was the omission of linguistic rules in the production of the target language. An example from Ellis (1994) is as follows: You like sing?

Do you like to sing?

d) False Concept Hypothesis

This source of error occurs when the students misinterpret the target language rule which results in misusing or misformation of the grammatical elements. Richard (1974) suggested that the misinterpretation of the English rule cause error utterances in English. An example from Ellis (1994) is as follows:

It was happened last Sunday*

It was last Sunday.

\section{Morphological Error}

Morphological errors are errors formed or made when the morphological aspect of grammar is being tainted, or misinformed. Morphology is the structure of words; it is the relation on how words are formed and how it fits together. If these rules are wrongly applied by the second language learners this means that they have committed morphological errors, even though they have prior knowledge pertaining the rules.

Richard (1971, cited in Khansir, 2012) categorizes four types of errors which are (a) overgeneralization: learner creates a similar structure on the basis of experience of the other structure, (b) ignorance of the rules restrictions: language learner applies the rules of context in a situation that they do not compromise, (c) incomplete application of the rules: the correct form of rules learned is not applied in a correct manner, and (d) false concept hypothesis: misassumption of the rules learnt, as language learners do not fully grasp the comprehension of the target language.

Morphological errors can be classified into several categories, i.e Affixation-Related Errors: Affixation-related errors arise as a result of misuse of either prefixes or suffixes; Morphological errors arising as a result of wrong insertion of past tense; Compound Related Errors: Compounding is a morphological process which consists in the combination of at least two free morphemes; Failure to use the marker (-er); ConversionRelated Errors; Using of plural in noun phrases

\section{Syntactic Error}

Syntax is the study about various aspects of how sentences are formed and how they are understood. Syntax is the study of how the words are combined to form the sentences and the rules which govern the formation of sentences (Haspelmath, 2002). In linguistics, its is the set of rules principles and processes that govern the structure of sentences in a given language, specifically word order. The term syntax is also used to refer to the study of such principles and processes. Scalise (2012) considers syntax a taxonomical device to reach broad generalizations across languages. Every sentence is a sequence of words, but not every sequence of words is a sentence. Sequence of words that conform to the rules of syntax are said to be well formed or grammatical and those that violate the syntactic rules are therefore ungrammatical. "the scope of syntax is in phrase, clause, and the sentence level" (Hanafi, 2003:3)

Syntactic errors can be classified into several categories, ie Concord in using auxiliaries; Errors in using SVO (subject verb object) Pattern; Errors In Using Articles; Errors In Using Preposition; Errors In Using Correct Form Of Tense; Errors In Using Conjunctions

\section{The Essence of Writing}

Writing is a process, while the results of the process are essays. Furthermore Byrne (1988) quoted by Karevianti (2004: 1) says that in writing we should organize our sentences carefully to make our meaning explicit without the help of feedback from the readers, on the other hand, we don't normally have to write quickly, we can rewrite and revise our sentences until we are satisfied that we have expressed our meaning.

In writing we should arrange sentences carefully so that our intentions are conveyed explicitly without the input from the reader. We should be able to write and improve the sentence until we get satisfaction.

Writing is very important in our live, it is an act of communication between the writer and the reader about some topics. It can fulfill some purposes, such as; giving information, sending 
messages, and persuading the audience to accept the ideas (Grundy and Liew, 1996 in Kareviati, 2004: 1).

While Feez and Joyce (1998: 1) say that writing is the craft of creating written text, they both make analogies about a writer and a carpenter. Both of these jobs need to prepare materials before making a product. Ofcourse the materials prepared by writers and carpenters are different. A writer needs materials to work such as paragraphs, sentences, collections of words, etc., while a carpenter need wood, glue, sandpaper and others.

While Halliday (as mentioned by Nunan, 1999: 275) asserts that written language is applied for the following purposes:

1) For action

For example public signs, product lables, television and radio guides, bills, menus, telephone directories, ballot papers, and computer manuals.

2) For information

For example newspaper, current affair magazines, advertisement, and political pamphlete.

3) For entertainment

For example comic strips, fiction books, poetry and drama, newspaper features, and film subtitles.

Based on the definition above, it can be concluded that writing is an activity to express or convey ideas in written language such as stories, books, poems and so on.

\section{Recount Text}

In a Recount text, the students must retell the sequence of events or experiences which they have got in the past (Nafisah and Kurniawan, 2007:65). Retelling past event intends to entertain or inform others what happened and when it happened (Gerot and Wignell 1995:194). It means that the students are expected to be able to write their past experience by learning Recount. It can be their personal diaries, letters, biographies, and speeches (Anderson and Anderson, 2003:49).

Eventhough Recount text had been studied since junior high school, sometimes the students had problems in writing it. Therefore, the researcher analyzes students' Recount text. It is because in writing Recount text, the students should apply the linguistic features of Recount in their text including specific participants, circumstance of time and place, first person, additive conjunction, material process, and past tense (Gerot and Wignell, 1995:194).

\section{METHOD}

In order to identify and classify the errors committed by the students, a mixed-method approach was implemented in this research. Document analysis, according to Bowen (2014), is the process of evaluating documents which can be done in both printed and electronic data.

Participants of this study were 70 students of tenth grade students of SMK Negeri 9 Kota Bekasi. The students were asked to write a recount text about last holiday consisting of at least 2 paragraphs and not less than 150 words

This research employed document analysis in obtaining the results. The short recount text written by the students were analysed using Corder's (1974) Error Analysis Procedure. Corder introduced five steps in analysing errors which are; choosing the language corpus, identifying the errors in the corpus, classifying the errors, explaining the errors and evaluating the errors. These steps were taken into measure in this study. Dulay, Burt and Krashen's (1982) Surface Strategy Taxonomy was used to group the errors accordingly. There are four classifications of in the taxonomy which are omission, addition, misinformation and misordering. The data classified was converted into percentages and presented in the table to give a clearer overview of the findings of the research

\section{FINDING AND DISCUSSION Morphological Errors}

After analyzing all data, the researcher finds 169 errors, 56 of them belong to morphological errors. These errors can be classified into five categories, ie singular, plural, possessive adjective, to infivinite, and simple past form as seen in the table below 
1) Singular errors

\begin{tabular}{cll}
\hline No & \multicolumn{1}{c}{ Students' sentences } & \multicolumn{1}{c}{ Reconstruction } \\
\hline $\mathbf{1}$ & There is a traffic jam for a minutes & There is a traffic jam for minutes \\
\hline $\mathbf{2}$ & After carrying out national exams & After national exam \\
\hline $\mathbf{3}$ & One experiences I want to tell is... & I want to tell an experience \\
\hline $\mathbf{4}$ & I get a lot of experience & I got a lot of experiences \\
\hline
\end{tabular}

2) Plural errors

\begin{tabular}{cll}
\hline No & \multicolumn{1}{c}{ Students' sentences } & \multicolumn{1}{c}{ Reconstruction } \\
\hline $\mathbf{1}$ & I saw beautiful scenery and many mountain & I saw beautiful scenery and mountainous \\
\hline $\mathbf{2}$ & There are many very unique tradition & There are many unique traditions \\
\hline $\mathbf{3}$ & In here I have to much amazing experience & I have many amazing experiences here \\
\hline $\mathbf{4}$ & There I have many friend's & I had many friends there \\
& & \\
\hline $\mathbf{5}$ & I was have some awesome experience & I had some awesome experiences
\end{tabular}

In this category, students make mistakes in the plural and singular rules which is a problem for Indonesians who learn English because in
Indonesia there are no suffix -s for plural objects. In this case, students often generalize by using Indonesian language rules in English (overgeneralization)

3) possessive adjective errors

\begin{tabular}{cll}
\hline No & \multicolumn{1}{c}{ Students' sentences } & \multicolumn{1}{c}{ Reconstruction } \\
\hline $\mathbf{1}$ & I home town in Solo & My home town is Solo \\
\hline $\mathbf{2}$ & I am to home town & I went to my home town \\
\hline $\mathbf{3}$ & I went to grandma house & I went to grandma's house \\
\hline $\mathbf{4}$ & We go use my family car's & We went there by family's car \\
\hline $\mathbf{5}$ & Because it's money is not my & Because the money is not mine \\
\hline
\end{tabular}

In this category students make mistakes in the use of pronouns. This is caused by inaccuracy of students or carelessness in which students actually already understand the rules of using pronouns but they are not careful in the application.

4) To infinitive errors

\begin{tabular}{cll}
\hline No & \multicolumn{1}{c}{ Students' sentences } & \multicolumn{1}{c}{ Reconstruction } \\
\hline $\mathbf{1}$ & I went to my home town for spend the day & $\begin{array}{l}\text { I went to my home town to spend the } \\
\text { day }\end{array}$ \\
\hline $\mathbf{2}$ & I went to my grandma's grave for pray & $\begin{array}{l}\text { I went to my grandma's grave to } \\
\text { pray }\end{array}$ \\
\hline $\mathbf{3}$ & Prepare to gived grandma & Prepared to give grandma \\
\hline $\mathbf{4}$ & Decided to left home & Decided to leave home \\
\hline $\mathbf{5}$ & When I wanted to go left home & When I wanted to leave home \\
\hline
\end{tabular}

In this category students make mistakes in terms of using to infinitive, the error is influenced by the use of recipient's mother tongue, generally it is because of lack of language control and lack of mastery of the recipient language. This is often happen to bilingualists who are learning a second language, both national and foreign languages. In the use of the second language, language users sometimes lack of control. 
5) Simple past errors

\begin{tabular}{cll}
\hline No & \multicolumn{1}{c}{ Students' sentences } & \multicolumn{1}{c}{ Reconstruction } \\
\hline $\mathbf{1}$ & My family and I make the ketupat & My family and I made ketupat \\
\hline $\mathbf{2}$ & I'm packing my important stuff & I packed my important things \\
\hline $\mathbf{3}$ & I was arrived & I arrived \\
\hline $\mathbf{4}$ & And I sleep in the car & And I slept in the car \\
\hline $\mathbf{5}$ & And then I see takbiran & And then I saw takbiran \\
\hline
\end{tabular}

In this category, students make mistakes in past verb formation where in terms of second language learning theory it is called overgeneralization because students sometimes apply a rule that has been studied previously in all situations without thinking that there are some exceptions. For example past tense word formation where in English we recognize regular verbs and irregular verbs

\section{Syntactical Errors}

In this research, the researcher finds 113 errors. These errors can be classified into three categories, ie omission, addition and misformation as seen in the table below

1) Omission of Errors

\begin{tabular}{cll}
\hline No & \multicolumn{1}{c}{ Students' sentences } & \multicolumn{1}{c}{ Reconstruction } \\
\hline $\mathbf{1}$ & I went back home and I happy & $\begin{array}{l}\text { I went back home and I was } \\
\text { happy }\end{array}$ \\
\hline $\mathbf{2}$ & We traffic jam & We were in a traffic jam \\
\hline $\mathbf{3}$ & We tiring but fun & We were tired but fun \\
\hline $\mathbf{4}$ & We are tiring but is fun & We were tired but it was fun \\
\hline $\mathbf{5}$ & We are very happy because can meet the family & $\begin{array}{l}\text { We were very happy because we } \\
\text { can meet the family }\end{array}$ \\
\hline
\end{tabular}

In this category students leave one or more language elements needed in a phrase or sentence. As a result there is a deviation in the construction of phrases or sentences. Seen from the findings of errors in this category, the factor most cause errors in this element is interference. In accordance with the theory of language error analysis that uses the language comparison method, the most reason why interference is likely to be the cause is because the formation of the phrase structure in Indonesian is different from English. In English there are different syntax points of conditions of use.

2) additional errors

\begin{tabular}{cll}
\hline No & \multicolumn{1}{c}{ Students' sentences } & \multicolumn{1}{c}{ Reconstruction } \\
\hline $\mathbf{1}$ & I left to went home town & I left and went to home town \\
\hline $\mathbf{2}$ & My family and I went to home by car & $\begin{array}{l}\text { My family and I went home by } \\
\text { car }\end{array}$ \\
\hline $\mathbf{3}$ & I prepare to gived grandma & I prepared to give grandma \\
\hline $\mathbf{4}$ & The thieft can not to go & The thieft can not go \\
\hline $\mathbf{5}$ & When takbiran to come & When takbiran came \\
\hline
\end{tabular}

In this category students add one or more language elements needed in a phrase or sentence. As a result there is a deviation of phrase or sentence construction. Judging from the findings of errors in this category, the factor most to cause errors in this element is interference where the formation of word structures in Indonesian is different from English. In English there are syntax points that are not in Indonesian, or if there are different conditions of use. For example, articles in Indonesian cannot be matched for use in English so knowledge of the first language does 
not facilitate second language learning. Therefore errors that occur can be made by negative transfer of the source language to the target language or also called interference.

3) misformation

\begin{tabular}{cll}
\hline No & \multicolumn{1}{c}{ Students' sentences } & \multicolumn{1}{c}{ Reconstruction } \\
\hline $\mathbf{1}$ & There is a traffic jam & There was a traffic jam \\
\hline $\mathbf{2}$ & It is tiring & It was tiring \\
\hline $\mathbf{3}$ & We are ready to pray taraweh & We were ready to pray \\
\hline $\mathbf{4}$ & We are tiring but is fun & We were tired but it was fun \\
\hline $\mathbf{5}$ & I am very happy because.... & I was very happy because.. \\
\hline $\mathbf{6}$ & It is lebaran day & It was lebaran day \\
\hline $\mathbf{7}$ & I am taking a rest & I took a rest \\
\hline $\mathbf{8}$ & I am spent the day & I spent the day \\
\hline
\end{tabular}

In this category students make mistakes in producing a phrase or sentence using the wrong structural form as a result of phrase construction or sentence becomes wrong or deviates from the rules of language. Seen from the findings of errors in this category, the factors most cause errors in this element are intralingual where the language error comes from inadequate mastery of the second language. Besides this error also occurs due to the influence of the mother tongue so students make sentences or translate sentences not in accordance with the rules of the target language.

After grouping into the types of errors, the researcher found 56 errors in morphological aspects and 113 errors in syntactic aspects. The tabulated errors are shown in the following table

Tabel 1

Errors Distribution

\begin{tabular}{cccc}
\hline No & Jenis Kesalahan & Total & Persentase \\
\hline $\mathbf{1}$ & Morfologi & 56 & 33.14 \\
\hline $\mathbf{2}$ & Sintaksis & 113 & 66.86 \\
\hline & & $\mathbf{1 6 9}$ & $\mathbf{1 0 0 \%}$ \\
\hline
\end{tabular}

The table above shows that the most errors are in the syntactic aspect with the number of errors $113(66.86 \%)$ and the smallest number of errors is in the morphological aspect with the number of errors $56(33.14 \%)$.

From the analysis, it can be concluded that the ability of tenth grade students of SMKN 9 Bekasi in writing recount essays is quite good, however there needs attention to be better especially in morphological aspects, especially in the category of past verb formation and syntactic aspects in particular in the word selection or diction category.

\section{CONCLUSION}

The students involved in this study face difficulties and misconceptions about the rules and concepts of morphology in their writing. The first important factor which compounds most ESL learners' problems in the acquisition of English morphology is the inconsistency inherent in the language (Babalola and Akande, 2002). As per the perception of teachers, this inconsistency, that there are no fixed rules in the grammatical constructions lead to morphological errors like, the plural form of knife is knives and wife is wives, but the plural form of chief is not chieves. These inconsistencies are always problem creators for students as per the opinion of teachers.

The second is the overgeneralization and the misapplication of rules as far as school English language teachers are concerned. In most cases, students do over generalize or misapply certain morphological rules. Overgeneralization and misapplication of rules are usually the aftermath of the ignorance of certain restrictions in the opinion of teachers. Besides that, mother tongue interference is also major cause of morphological errors. Most errors especially the ones that have to do with suffixation, conversion and pronunciation are made as a result of the influence of the first language of the students on English

Regarding syntactic errors, it arises from negative first language interference on target 
p-ISSN 2540-8216, e-ISSN 2654-3745

https://journal.stibaiec-jakarta/ojs/index.php/jell

language structures, attitude of students, present method of teaching, lack of exposure to English language and intra language interference. The findings of this study demonstrate the utility of

\section{REFERENCES}

Anderson, M. and Anderson, K. (2003). Text types in English 1. Australia: Macmillan.

Bowen, C. (2014). Brown's stages of syntactic and morphological development. Retrieved from Speech Language Therapy: http://www.speech-language-therapy.com

Corder, S.P. (1981). Error analysis and interlanguage. New York: Oxford University Press employing systematic strategies for teaching syntactic and morphological structures of English language.

Gerot, L. and Wignell, P. (1995). Making sense of functional grammar. Australia: An Introductory Workbook.

Halliday, M.A.K. (1994). An Introduction to Functional Grammar (second ed.). China: Foreign language teaching and research press.

Nafisah, N. and kurniawan, E. (2007). Writing English for General Communication. Bandung: UPI PRESS 
Noening Poejilestari

An Analysis of Morphological and Syntactical Errors in Recount Text 